\title{
On Ageing Generation of Farmers: A Predictor Study on Agripreneurial Intentions among Selected Agriculture Students in Region XI, Philippines
}

\author{
Bryl I. Manigo ${ }^{a}$ \\ abryl.manigo@usep.edu.ph \\ ${ }^{a}$ Faculty, Department of Agricultural Sciences, College of Agriculture and Related Sciences, University of Southeastern Philippines, \\ Tagum-Mabini Campus, Apokon, Davao del Norte 8100
}

\begin{abstract}
The Philippine agriculture is threatened by the ageing generation of farmers mainly due to various stereotypes about farming. One way to revitalize the country's agriculture sector and entice the young generation to engage in farming is through agripreneurship. A study was conducted to predict the variables that influence the agripreneurial intentions of selected agriculture students in Davao Region, Philippines. Employing a quantitative descriptive research design, survey questionnaires were administered to 300 respondents from three tertiary state-run institutions across the region. Using binary logistics regression analysis, results revealed that among the socio-demographics, family agricultural land ownership reliably predicted agripreneurial intentions of students while the impact on other factors was insignificant. Furthermore, human behaviors were found to significantly impact their decisions towards agripreneurship. It also appeared that creativity, problem solving, and leadership and communication skills positively influenced agripreneurial intentions. These results provide useful idea to enhance the academes' teaching strategies in promoting agripreneurship.
\end{abstract}

Published by IJRP.ORG. Selection and/or peer-review under responsibility of International Journal of Research Publications (IJRP.ORG)

Keywords: Agripreneurship; Theory of Planned Behavior; Ageing Generation of Farmers; Binary Logistic Regression; Philippine Farming

\section{Introduction}

Despite the rise of technology in all aspect of human activities nowadays, agriculture has still been widely known and acknowledged as the mother of all sciences, the backbone of a nation's economy and the maintainer of human life (Thompson, 2017; Jones \& Ejeta, 2016). In the Philippines, the economy is greatly dependent on agriculture because of its strong impact on the economy's strength and stability (Habito \& Briones, 2005). The agriculture industry provides livelihood and employment among its constituents and produces exportable commodities to other countries such as fresh bananas, pineapples, mangoes and sugarcane products (PSA, 2018).

Despite its beneficial contribution to the economy and the opportunities it brought to Filipinos, the agriculture sector has been confronted with various challenges and serious threats. The ageing generation of farmers has been considered as one of the most unrelenting challenge facing the Philippine agriculture today (Arado, 2018; Elauria, 2015). The number of people entering the industry is decreasing, mainly due to various stereotypes about farming which greatly contributed to the decline in the employment rate of the agriculture sector (Elauria, 2015). The government had actually devised strategies to encourage the youth to engage in farming. In fact, a report from the Commission on Higher Education positioned agriculture as a priority program for incoming college students (CHED, 2014). The country has more than enough graduates of 
agricultural courses accounting to about 46,000 agriculture students from 112 universities/colleges. However, most of them do not actually end up as farmers. Instead, they go to the service sector such as government, industry or business because they do not think of agriculture or farming as a profession, making it less attractive for younger people (Elauria, 2015). Moreover, they do not like to go into agriculture because of the level of difficulty and the supposedly low income being associated with it. Data from the Philippine Statistics Authority (PSA) showed that agriculture receives the lowest average daily basic wage of Php 220.26 for a farm worker, versus the national average of Php 415.17 (PSA, 2017).

It was also documented that the average age of farmers in 2013 was 57 (Arado, 2018; Elauria, 2015). With an average life span of 70, a shortage in the labor supply of farmers is expected in the next 15 years. Much of the youth today ignored farming because of its apparent hardships and its continuous association with poverty, so no farmer would want their children to follow their footsteps. Most rural families instead want their children to pursue more lucrative jobs in commercial centers in the nearby cities (Elauria, 2015).

Apart from our economic dependence to agriculture, entrepreneurship is also perceived to bring economic welfare and may contribute significantly in nation's future wealth. Entrepreneurship creates jobs which consequently generate more opportunities, and address unemployment rate in the Philippines that is constantly increasing. The students of today's generation are deemed as the future entrepreneurs of the country (Ramos, 2014). Thus, with the legislation of Republic Act No. 10679 or the Youth Entrepreneurship Act of 2014, the Philippine government is tasked to promote the sustained development of young Filipinos whose aptitude and skill in the field of entrepreneurship as well as with finance shall be encouraged and honed through education and specialized training programs. Among the standards and competencies identified and covered with the law is the agri-entrepreneurship. Furthermore, the state shall establish, maintain, and support a complete, adequate, and integrated system of education and training to encourage the entrepreneurial spirit among the youth as well as support and promote the growth of young entrepreneurs nationwide (RA 10679, 2014).

The production of food to meet the increasing demands of the ever growing population calls for an urgent need of young agricultural practitioners of the country to participate in this advocacy (Cudis, 2019). According to Dr. William Dar (2016), a Filipino horticulturist and public servant, one way to entice the young generation to engage in farming and revitalize the country's agriculture sector is through entrepreneurship in agriculture or agripreneurship.

Agripreneurship is a relatively new concept that yields profitable blend of agriculture and entrepreneurship which turns a farm into an agribusiness (Otache, 2017; Bairwa et al., 2014). Hansson et al. (2013) further incorporate agripreneurship on other income-generating strategies such as off-farm employment and multiple business holdings. Entrepreneurship in agriculture is defined as the creation of growth or gain under conditions of risk and uncertainty in agriculture. Agripreneurship have been used in other countries as a tool in the upliftment of agriculture because it has the potential to contribute to a range of social and economic development such as employment generation, income generation, poverty reduction and improvements in nutrition, health and overall food security in the national economy (Bairwa et al., 2014). Agripreneurship opens a lot of possibilities especially to the youth as they are more receptive to adopting and even experimenting various technologies that can be used in farm, even more innovative than those who have been into farming for many years (Dar, 2016).

With this direction, encouraging the youth to venture in the entrepreneurship of agriculture is indeed necessary. It must also be taken into consideration that engagement in entrepreneurial ideas or new venture development begins with inspiration, sustained attention and intention. Intentions guide in goal setting, communication, commitment, organization, and other kinds of work. However, intentions to pursue in business is believed to be affected by various significant factors - personal or environmental or the interplay of both. Empirical studies were already conducted to test entrepreneurial intentions of an individual and concluded several results. Individual level characteristics of the entrepreneur have been shown to largely influence entrepreneurial intentions (Rocha et al., 2015). These characteristics include the 
entrepreneur's attitudes towards entrepreneurship, demographics, entrepreneurial exit specificities, entrepreneurial perceptions, human capital and social capital.

Significantly, Ajzen's Theory of Planned Behavior (TPB) has been used as a validated framework to explain entrepreneurial intention (Krueger at al., 2000). This theory started as the Theory of Reasoned Action in 1980 which aimed to predict an individual's intention to engage in a behavior at a specific time and place. The theory was intended to explain all behaviors over which people have the ability to exert self-control. The TPB has been used successfully to predict and explain a wide range of health behaviors and intentions including smoking, drinking, health services utilization, breastfeeding, and substance use, among others. The TPB states that behavioral achievement depends on both motivation (intention) and ability (behavioral control). It distinguishes between three types of beliefs - behavioral, normative, and control. The TPB is comprised of six constructs that collectively represent a person's actual control over the behaviour which includes attitude, behavioral intention, subjective norms, social norms, perceived power and perceived behavioral control.

Individual perceptions play a significant part in influencing the interests of the young generation in agripreneurship (Magagula \& Tsvakirai, 2020). This is because individuals decide to start an entrepreneurial activity if it is perceived to be more desirable and feasible than other alternatives (Liñán et al., 2011). In this study, the attitude, subjective norms and perceived behavioural control constructs will be used similar with the entrepreneurial intentions study conducted by Ibrahim et al. (2018). Attitudes refers to the degree to which a person has a favorable or unfavorable evaluation of the behavior of interest. On the other hand, subjective norms are beliefs about whether most people approve or disapprove of the behavior while perceived behavioral control refers to a person's perception of the ease or difficulty of performing the behavior of interest. Moreover, attitude was also found to be a significant predictor of intention for engagement in sustainable agricultural practices (Fielding et al, 2008).

Several skills have been identified as critical to the success of farm ventures (Mcelwee, 2008; Mcelwee \& Bosworth, 2010). Entrepreneurial skills are among the set of skills identified as being critical to enterprise success based on the writings of Lyons in 2002 along with technical skills, managerial skills, and personal maturity skills. In the study of Liñán (2008), he suggested that there is a strong case for developing skills such as opportunity recognition, creativity, problem solving, leadership and communication, innovation and networking.

With these literatures, it was hypothesized that the socio-demographic variables, human behaviour and entrepreneurial skills and capabilities affects the entrepreneurial intentions of the students. As engagement in business always commenced with an expression of an intention, this research endeavor was explored to predict the variables that influence the agripreneurial intentions of agriculture students of selected State Colleges and Universities (SUCs) in Davao Region five (5) years after they graduate.

\section{Materials and Methodology}

A quantitative descriptive research design was employed using a researcher-designed "Agripreneurial Intention Survey Questionnaire". The survey was administered in Davao Region, Philippines from February to April 2019. To ensure smooth data gathering process, a face to face interview was done. The questionnaire was constructed and pre-tested to ensure the comprehensibility of questions, convenience of respondents, and optimal duration of the interview. The tool was further validated and tested for its reliability. Validation of instrument was done through expert consultation from three identified experts in the field of entrepreneurial research while the test of reliability was done by conducting pre-test and determining the Cronbach's alpha through reliability test in SPSS statistics software.

A total of 300 fourth year agriculture students participated in the survey which was randomized using a stratified random sampling which involves the process of segregation of respondents in each stratum (Sekaran 
$\&$ Bougie, 2016). The total number of participants was more than the total number identified following the Slovin's formula (Slovin, 1960). These participants are agriculture students who were currently enrolled on the $2^{\text {nd }}$ semester of the academic year 2018-2019 from three selected SUCs in Davao Region offering agriculture-related courses for more than ten years already. These tertiary academic institutions were (1) University of Southeastern Philippines (USeP), Tagum-Mabini Campus, Apokon and Mabini Units; (2) Davao Oriental State College of Science and Technology (DOSCST), Main - Mati City, San Isidro, Cateel and Banaybanay Campuses, Davao Oriental; and (3) Southern Philippines Agri-Business and Marine and Aquatic School of Technology (SPAMAST), Buhangin and Digos Campuses, Davao del Sur. Each SUCs were properly coordinated prior to the conduct of survey.

The agripreneurial intention served as the dependent variable and was measured based on the response of each respondents to either without intention (coded as 0) and with intention (coded as 1). On the other hand, the independent variables or predictors of the dependent variable include (1) Socio-demographic factors, (2) Human behaviour and (3) Entrepreneurial skills and capabilities. Socio-demographic factors include (1.a) sex, (1.b) age, (1.c) family business engagement, (1.d) monthly family income, and (1.e) family agricultural land ownership. On the other hand, human behaviour includes (2.a) attitude, (2.b) subjective norms, and (2.c) perceived behavioural controls while entrepreneurial skills and capabilities include (3.a) recognition of opportunity, (3.b) creativity, (3.c) problem solving skills, (3.d) leadership and communication skills, (3.e) development of new products and services, and (3.f) networking skills and making professional contacts.

This study sought to determine how the dependent variables change with variations in the independent (explanatory) variables. Since the dependent or response variable was measured in a dichotomous scale, the binary logistics regression analysis was found appropriate (Tabachnick et al, 2007).

\section{Results and Discussion}

\subsection{Test of Validity and Reliability of Questionnaire}

Prior to the conduct of the survey, the instrument which was validated through expert consultation was pre-tested to 200 students randomly selected from the total population of the desired respondents. The result of the pre-test was analyzed to determine the reliability of the tool.

Table 1. Reliability Statistics of Questionnaire

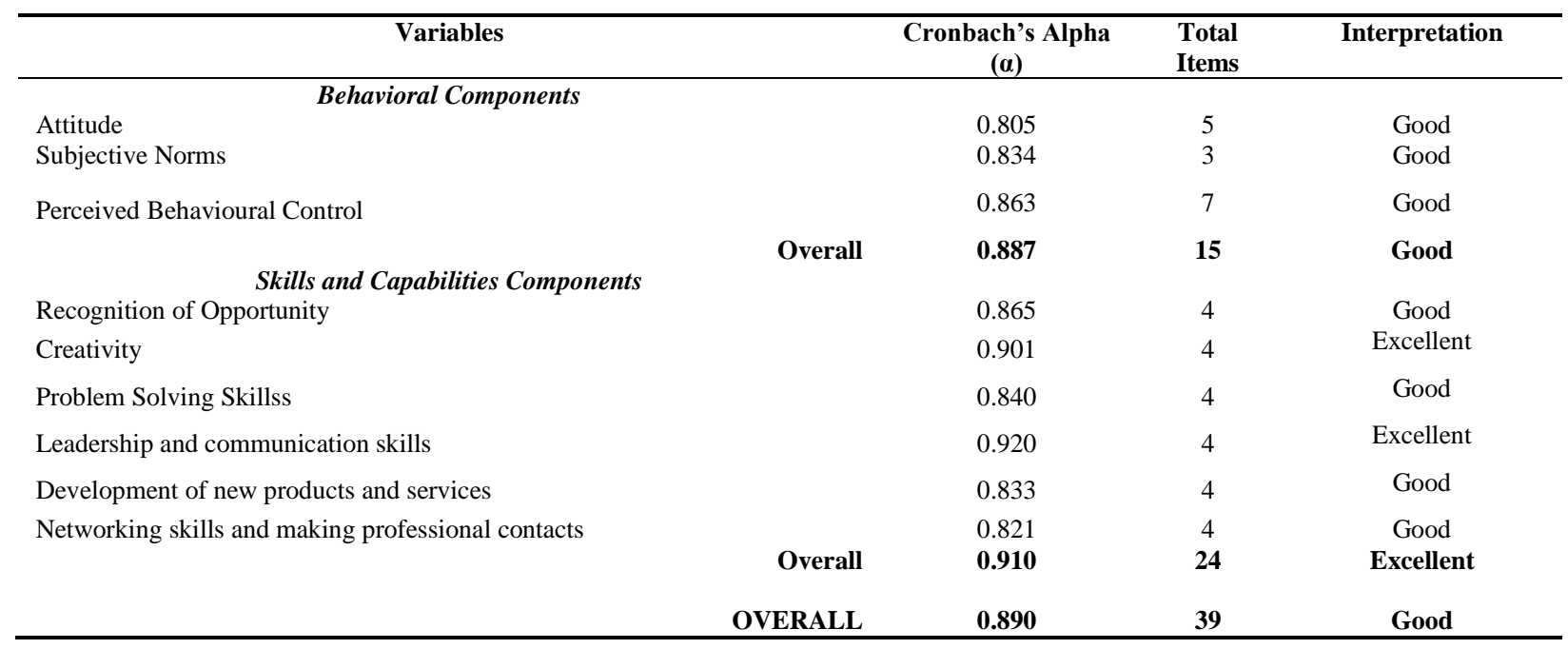


Table 1 shows the reliability statistics of the questionnaire which showed the Cronbach's alpha higher than 0.80 which indicates a high level of internal consistency for the scale set in each items based on the rule of thumb provided by George and Mallery (2003, p.231).

\subsection{Characteristics and Percentage distribution of the Respondents}

Descriptive analysis was done to determine the total number of samples participating in the agripreneurial intention survey. Based on the data from each SUCs, there are 524 fourth year regular agriculture students currently enrolled for the second semester of the academic year 2018-2019. Out from this population, 300 students were selected which was way higher using the Slovin's formula of (Slovin, 1960).

Table 2. Demographic profile of the respondents $(n=300)$

\begin{tabular}{|c|c|c|c|c|}
\hline $\begin{array}{l}\text { Demographic Information } \\
\end{array}$ & $\boldsymbol{F}$ & $\%$ & Mean & SD \\
\hline \multicolumn{5}{|l|}{ Sex } \\
\hline Male & 122 & $41 \%$ & & \\
\hline Female & 178 & $59 \%$ & & \\
\hline \multicolumn{5}{|l|}{ Age } \\
\hline $18-20$ & 78 & $26 \%$ & & \\
\hline $21-23$ & 145 & $48 \%$ & 21.73 & 1.91 \\
\hline $24-26$ & 54 & $18 \%$ & & \\
\hline $27-29$ & 23 & $8 \%$ & & \\
\hline \multicolumn{5}{|l|}{ SUC/School } \\
\hline USeP & 145 & $48 \%$ & & \\
\hline DOSCTS/DORSU & 108 & $36 \%$ & & \\
\hline SPAMAST & 47 & $16 \%$ & & \\
\hline \multicolumn{5}{|l|}{ Course Major/Specialization } \\
\hline General (No specific major) & 125 & $42 \%$ & & \\
\hline Crop Science & 77 & $26 \%$ & & \\
\hline Animal Science & 54 & $18 \%$ & & \\
\hline Agricultural Economics \& Marketing (Enterprise Management) & 33 & $11 \%$ & & \\
\hline Crop Protection (Plant Pathology) & 11 & $4 \%$ & & \\
\hline \multicolumn{5}{|l|}{ Family Business Engagement } \\
\hline Without Family Business & 198 & $66 \%$ & & \\
\hline With Family Business (Not Agri-related) & 55 & $18 \%$ & & \\
\hline With Family Business (Agri-related) & 47 & $16 \%$ & & \\
\hline \multicolumn{5}{|l|}{ Family Income } \\
\hline Below Php 10,000 & 210 & $70 \%$ & & \\
\hline Php10,000 - 20,000 & 71 & $24 \%$ & & \\
\hline Php20,001 - 30,000 & 19 & $6 \%$ & & \\
\hline \multicolumn{5}{|l|}{ Family Agricultural Land Ownership } \\
\hline Without Ownership & 198 & $66 \%$ & & \\
\hline With Ownership & 102 & $34 \%$ & & \\
\hline
\end{tabular}


Table 2 shows the demographic profile of the respondents. It was observed that most of the respondents are female $(59 \%)$ compared to male $(41 \%)$ and majority of them are aged 21-23 with an average age of 21.73 years old. Almost half of the respondents were from USeP or about $48 \%$ while DOSCST and SPAMAST have $36 \%$ and $16 \%$ share, respectively. In terms of their course major or specialization, majority of them or $48 \%$ have no specific major since they are currently taking general agriculture courses/subjects, while crop science, animal science, agricultural economics and marketing and crop protection have $26 \%$, $18 \%, 11 \%$ and $4 \%$, respectively.

When asked if their family were engaged in any business activities, 198 or $66 \%$ have no business engagement. The remaining 102 respondents have business engagement but the nature of business of $18 \%$ (55 respondents) were not agri-related while $16 \%$ (47 respondents) are agri-related.

The average monthly income of the 210 respondents was below Php 10,000.00, while 71 respondents ranged from Php 10,000.00 - Php 20,000.00 and only 19 respondents have an average monthly income of Php 20,001.00 - Php 30,000.00.

Majority of the respondent's family have no ownership with any agricultural land which account for 198 or $66 \%$ while the remaining 102 or $34 \%$ have family owned agricultural land.

As illustrated in figure 1, a staggering total percentage of $93 \%$ responded that they intend to engage in agripreneurial activities five years after they graduate in college. That constitute a total of 279 students who gave positive response which signifies that at this level of their studies, they are inclined towards agripreneurship. Conversely, only $7 \%$ or 21 students answered that they have no agripreneurial intentions.

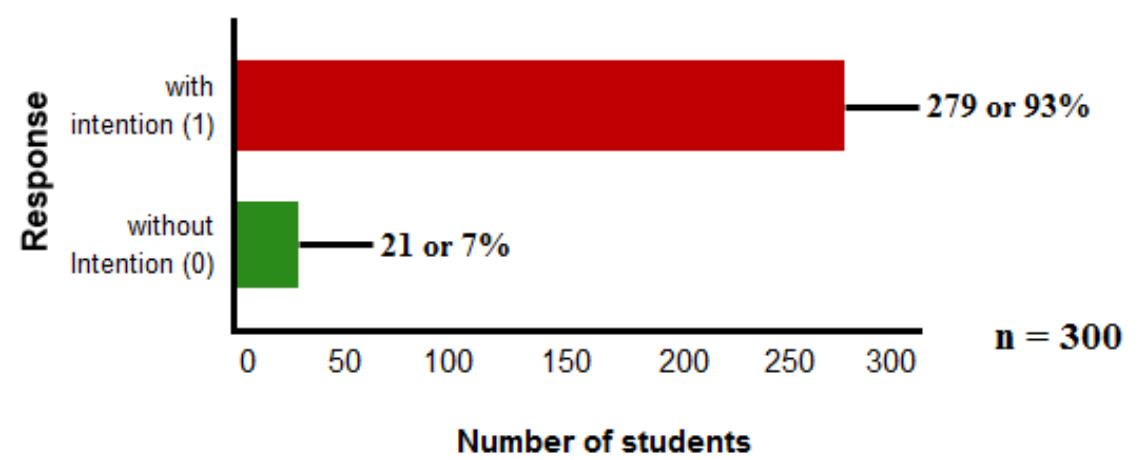

Fig. 1. Responses of students in relation to their intentions toward Agripreneurship.

\subsection{Agripreneurial Intention of Students through Binary Logistic Regression Analysis}

Table 3 revealed the results of logistic regression analysis with agripreneurial intentions $(0=$ without intention; 1 = with intention) as dependent variable. The resulting model showed that out of 14 predictor variables, only seven significantly influenced the agripreneurial intentions of the respondents five years after they will finish their college education. These variables include family agricultural land ownership under the socio demographic factor; attitude, subjective norms, and perceived behavioural controls under the human behaviour factor while creativity, problem solving skills, leadership and communication skills under the entrepreneurial skills and capabilities. 
Table 3. Predictors of agripreneurial intentions results based on binary logistic regression analysis

Determinants/Predictors

B Wald Statistics

P-Value $\quad \operatorname{Exp}(\boldsymbol{B})$

\begin{tabular}{lcccc}
\hline Socio-Demographic & & & & \\
$\quad$ Sex & 2.993 & 0.767 & $0.334 \mathbf{~ n s}$ & 1.62 \\
Age & 1.63 & 2.022 & $0.870 \mathbf{~ n s}$ & 3.20 \\
Family Business Engagement & -1.198 & 0.014 & $0.906 \mathbf{~ n s}$ & 0.82 \\
$\quad$ Monthly Family Income & -1.116 & 1.520 & $0.463 \mathbf{~ n s}$ & 0.33 \\
$\quad$ Family Agricultural Land Ownership & -5.202 & 4.347 & $0.037 *$ & 2.60 \\
Human Behaviour & & & & \\
$\quad$ Attitude & 5.351 & 3.607 & $0.048 *$ & 210.84 \\
$\quad$ Subjective Norms & 4.376 & 4.406 & $0.036 *$ & 79.53 \\
$\quad$ Perceived Behavioural Controls & 2.451 & 3.221 & $0.043 *$ & 41.61 \\
Entrepreneurial Skills and Capabilities & & & & \\
$\quad$ Recognition of Opportunity & 0.072 & 0.087 & $0.890 \mathbf{~ n s}$ & 1.075 \\
$\quad$ Creativity & 2.21 & 2.870 & $0.023 *$ & 7.21 \\
$\quad$ Problem Solving & 2.06 & 4.323 & $0.045 *$ & 6.56 \\
$\quad$ Leadership and Communication Skills & 2.441 & 3.233 & $0.028 *$ & 7.03 \\
$\quad$ Product and Services Development & 0.493 & 0.776 & $0.670 \mathbf{~ n s}$ & 1.64 \\
$\quad$ Networking Skills & 0.002 & 0.223 & $0.620 \mathbf{~ n s}$ & 1.00 \\
\hline
\end{tabular}

* Significant at .05 level; ns means not significant

Based on the exponentiated logistic coefficient [Exp (ß)] or odds ratio, respondents without family agricultural land ownership are 2.60 times more likely to engage in agripreneurship than those respondents whose family owned an agricultural land. The beta figure of this variable showing negative value $(\beta=-5.202)$ implies that the more their family own an agricultural land, the lesser they will engage in agripreneurship. This study implies that holding an agricultural land brings negative effect on the inclination of students towards engagement in agripreneurial activities. It poses an ironic and undesirable condition for students which needs urgent attention. Instead of having the motivation to engage in the business of farming while having a family owned agricultural land, they find it less attractive for them (Elauria, 2015).

However, in the 2019 Rural Development Report, he emphasized that in order to entice the young generation to engage in farming, they must be provided with land and other agrarian resources that will serve as a cornerstone of rural youth policy. He said that this endeavor is a more effective support for small-scale agriculture and opportunities for young rural men and women to engage in farming (White, 2019). This youth-inclusive agricultural development agenda for agricultural countries is not aligned with the perceptions of the students as manifested in the results of this study. It can be noted that the young generation nowadays are not enticed to engage in agriculture and follow the footsteps of their parents probably due to the perceived hardships and poverty that they usually associate in farming (Elauria, 2015).

In terms of human behaviour, attitude emerged the strongest predictor with an odds ratio of 210.84 . This entails that those respondents with more favourable attitude have higher agripreneurial intentions compared to those who have less favorable attitude. Positive numbers of the beta coefficient $(\beta=5.351)$ indicate that 
attitude influence the agripreneurial intentions to its desired direction. Similarly, respondents with more encouraging subjective norms are 79.53 times most likely to develop agripreneurial intentions than those who have less encouraging beliefs. Respondents with more positive perceived behavioural control are 41.61 more likely to engage in agripreneurial intentions that those who have lesser positive perception of the ease of performing the behavior of interest.

These results had strong support of the predictive ability of the theory of planned behaviour. According to the TPB, entrepreneurial intention is the effort a person will put forth to carry out an entrepreneurial behavior. These intentions may be influenced directly by motivational antecedents (Ajzen, 1991; Liñan, 2004), such as attitudes toward the desirability of an entrepreneurial career; subjective norms, including perceived family expectations and beliefs to perform the behavior; and perceived behavioral control (Naia, 2017).

Creativity, problem solving and leadership and communication skills are among the entrepreneurial skills and capabilities constructs that positively influenced agripreneurial intentions of the respondents. Respondents with creative skills are 7.21 times more likely to develop agripreneurial intentions than those who are less creative. Results further entails that the more the students are creative, the more they desired to engage in agripreneurship. In the same manner, students with good problem solving skills are 6.56 times more likely to engage in agripreneurial activites. It was also showed that those respondents who are good in leadership and communication skills have 7.03 times more probability to practice agripreneurship.

This outcomes are similar with the study of Ramos (2014) which yields these three agripreneurial skills and capabilities. In her study, students believed that creativity is a very significant skill needed to become an entrepreneur. On the other hand, networking skill and making professional contact are believed to be the least capability or skills an entrepreneur must possess. Most of the students also agreed that they need to be creative and have good communication skills to start and manage their own business. Abbasi et al. (2011) also recognizes role of effective communications for enhancing leadership and entrepreneurial skills in university students. It was also demonstrated in the study of Payne (2005) that the force of communication competence, inspiration, and cognitive skills was on managerial performance which is important in running an enterprise.

\section{Conclusions and Recommendations}

Engagement in agripreneurship always starts with a manifestation of an intention. This study yield significant indicators that influence or predict the likelihood of students to engage in agripreneurship five years after they graduate. Among the independent or predictor variables identified, family agricultural land ownership emerged to significantly influence their agripreneurial intentions while the impact on other socio demographic factors was insignificant. On the other hand, human behaviours such as attitude, subjective norms and perceived behavioural controls showed strong correlation. It also appeared that among the entrepreneurial skills and capabilities identified, creativity, problem solving, and leadership and communication skills positively influenced agripreneurial intentions. These predictors provide useful idea in the academe to enhance the current teaching strategies to promote agripreneurship among its students and somehow remediate the ageing generation of farmers.

It is recommended that the skills emerged as significant be integrated in the strategies of teaching workforce. Furthermore, another study evaluating the respondents of this study to assess if they really engaged in agripreneurial activities five years after they graduate.

\section{Acknowledgements}

The researcher would like to extend his heartfelt thanks to all the faculty, staff and students of USeP, DOSCST and SPAMAST for allowing him to conduct his study in their respective SUCs. 


\section{References}

Abbasi, M. H., Siddiqi, A., \& Azim, R. U. A. (2011). Role of effective communications for enhancing leadership and entrepreneurial skills in university students. International Journal of Business and Social Science, 2(10).

Ajzen, I., 1991. The theory of planned behavior. Organizational behavior and human decision process. 1991; 50: 179-211.

Arado, J., 2018. DOT to develop farm tourism. Sunstar Philippines, February 12, $2018 . \quad$ Retrieved from https://www.sunstar.com.ph/article/418545.

Bairwa, S., Lakra, K., Kushwaha, S., Meena, L. and Kumar, P., 2014. Agripreneurship Development as a Tool to Upliftment of Agriculture. International Journal of Scientific and Research Publications, Volume 4, Issue 3, March 2014.

CHED, 2014. CHED priority courses for ay 2014-2015 to ay 2017-2018. Commission on Higher Education. Retrieved http://www.ched.gov.ph/wp-content/uploads/2014/05/cmo-01-series-of-2014-ched-priority-courses-for-ay-2014-2015-to-ay2017-20181.pdf.

Cudis, C., 2019. DA urges youth to take up farming. Philippine News Agency, November 13, 2019, 7:51 pm. Retrieved from: https://www.pna.gov.ph/articles/1085918

Dar, W., 2016. Agripreneurship. The Manila Times, December 30, $2016 . \quad$ Retrieved from: https://www.manilatimes.net/agripreneurship/304286/

Elauria, M., 2015. Farm land policy and financing program for young generation in the Philippines. CEM, UP-Los Banos. Fftc agricultural policy articles. Retrieved from: http://ap.fftc.agnet.org/files/ap_policy/448/448_ppt.pdf

Fielding, K.S., Terry, D.J., Masser, B.M., \& Hogg, M.A., 2008. Integrating social identity theory and the Theory of Planned Behaviour to explain decisions to engage in sustainable agricultural practices. British Journal of Social Psychology, 47(1), 23-48

George, D., \& Mallery, P., 2003. Reliability Analysis. SPSS for windows, step by step: A simple guide and reference, 14th Edn. Boston: Allyn \& Bacon, 222-232.

Habito, C., \& Briones, R., 2005. Philippine agriculture over the years: performance, policies and pitfalls. In conference entitled "policies to strengthen productivity in the Philippines," sponsored by the Asia-Europe meeting (ASEM) trust fund, Asian Institute of Management Policy Center, Foreign Investment Advisory Service, Philippines Institute of Development Studies and the World Bank, held in Makati City.

Hansson, H., Ferguson, R., Olofsson, R., and Rantamäki-lahtinen, R., 2013. Farmers' motives for diversifying their farm business - the influence of family. Journal of Rural Studies 32: 240-250. Doi: 10.1016/j.jrurstud.2013.07.002.

Ibrahim, S., Essa, E., and Afifi, O., 2018. Determinants of entrepreneurial intentions using theory of planned behavior. Retrieved from: https://www.researchgate.net/publication/323616845_determinants_of_entrepreneurial_intentions_using_theory_of_planned behavior

Jones, A.D., \& Ejeta, G., 2016. A new global agenda for nutrition and health: the importance of agriculture and food systems. Bulletin of the World Health Organization, 94(3), 228

Krueger, NF., Reilly MD, and Carsrud AL., 2000. Competing models of entrepreneurial intentions. J Bus Venturing. 2000; 15(5-6): 41132.

Liñán, F., 2004. Intention-based models of entrepreneurship education. Piccolaimpresa/Small Business. 2004; 3:11-35.

Liñán, F., 2008. Skill and value perception: How do they affect entrepreneurial intention? International entrepreneurship management.

Liñán, F., Santos, F.J., and J. Fernández, 2011. The influence of perceptions on potential entrepreneurs. International entrepreneurship and management journal 7 (3): 373-390. Doi: 10.1007/s11365-011-0199-7

Lyons, T.S., 2002. The entrepreneurial league system: transforming your community's economy through enterprise development. Washington, DC: The Appalachian Regional Commission.

Magagula, B., \& Tsvakirai, C.Z., 2020. Youth perceptions of agriculture: influence of cognitive processes on participation in Agripreneurship. Development In Practice, 30(2), 234-243.

Mcelwee G. and Bosworth G., 2010. Exploring the strategic skills of farmers across a typology of farm diversification approaches. Journal of Farm Management 13(12): 819-838.

Mcelwee, G., 2008. A taxonomy of entrepreneurial farmers. International Journal of Entrepreneurship and Small Business 6(3): 465-478.

Naia, A., Baptista, R., Biscaia, R., Januário, C., and Trigo, V., 2017. Entrepreneurial intentions of sport sciences students and theory of planned behavior. Motriz: rev. Educ. Fis. Vol.23 no.1 Rio Claro Jan./Mar. 2017

Otache, I., 2017. Agripreneurship development: A strategy for revamping Nigeria's economy from recession. African Journal of Economic and Management Studies.

Payne, H.J., 2005. Re-conceptualizing social skills in organizations: exploring the relationship between communication competence, job performance, and supervisory roles, Journal of Leadership \& Organizational Studies, Wntr.

PSA, 2017. Wage statistics: average daily basic pay of wage and salary workers. Philippine Statistics Authority. Retrieved from: https://psa.gov.ph/philippine-industry-yls/table/wage\%20statistics

PSA, 2018. Agricultural exports and imports, Philippine Statistics Authority, report no. 2018 - 4, September, 2018.

Ramos, A., 2014. Entrepreneurial intentions among business students in Batangas State University. Asia Pacific Journal of Multidisciplinary Research, volume 2, no. 4, August 2014.

Republic Act No. 10679, 2014. Youth Entrepreneurship Act of 2014: an act promoting entrepreneurship and financial education among Filipino youth. Retrieved from: https://bit.ly/2mtojwq

Rocha, V., Carneiro, A., \& Varum, C. A., 2015. Entry and exit dynamics of nascent business owners. Small business economics, 45(1), 
63-84. Doi:10.1007/s11187-015-9641-5\.

Sekaran, U., \& Bougie, R. (2016). Research methods for business: A skill building approach. John Wiley \& Sons.

Slovin, E., 1960. Slovin's formula for sampling technique. Retrieved on February, 13, 2013, p.2016.

Tabachnick, B.G., Fidell, L.S., \& Ullman, J.B., 2007. Using multivariate statistics (vol. 5, pp. 481-498). Boston, MA: Pearson.

Thompson, P.B., 2017. The spirit of the soil: agriculture and environmental ethics. Taylor \& Francis.

White, B., 2019. Rural youth, today and tomorrow. Rural Development Reports. IFAD. 